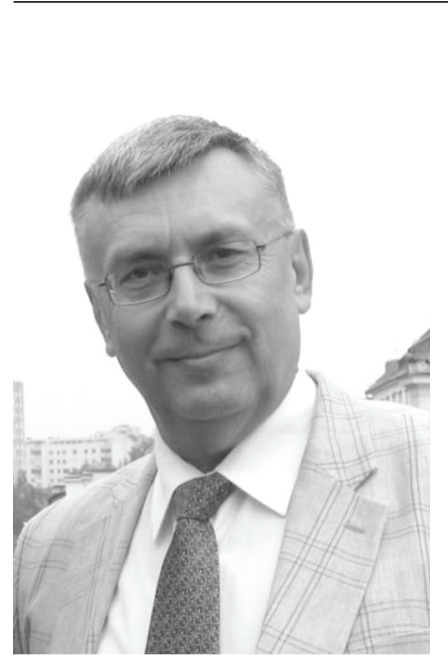

Rimantas Sliužinskas - prof. dr., Klaipèdos universiteto Filologijos katedros mokslo darbuotojas Moksliniai interesai: etnomuzikologija, muzikinè folkloristika, muzikinè antropologija, regioniniai ir lyginamieji muzikinio folkloro tyrimai El.paštas: r.sliuzinskas@gmail.com

Rimantas Sliužinskas - Prof. Dr., Research Fellow at Department of Philology, Klaipeda University

Research interests: etnomusicology, musical folkloristics, musical anthropology, regional and comparative musical folklore investigations

E-mail: r.sliuzinskas@gmail.com

\title{
Rimantas Sliužinskas
}

Klaipedos universitetas

\section{TRADICINIŲ MUZIKOS INSTRUMENT Ų IR INSTRUMENTINES MUZIKOS ISTORINE TERMINIJA}

\begin{abstract}
Anotacija
Straipsnis skirtas tradicinių muzikos instrumentų ir jų muzikos istorinei terminijai aptarti. Medžiaga tyrimams surinkta peržvelgus XIX a. pabaigos - XX a. pirmųjų dešimtmečių lietuviškus etnomuzikologinès literatūros šaltinius, siekiant aptikti ankstyviausius aptariamų muzikos instrumentų pavadinimų, jų konstrukcijos ir repertuaro aprašus. Daugiausia dèmesio skirta istoriniams Miko Petrausko (1873-1937), Prano Puskunigio (1860-1946), Justino Strimaičio (1895-1960), Mykolo Biržiškos (1882-1922), Adolfo Sabaliausko (1873-1950), Teodoro Brazio (1870-1930), kitų autorių tekstams. Šiuo aspektu sisteminiu būdu tradiciniai lietuvių muzikos instrumentai dar nebuvo pakankamai tyrinèti, tad šiame straipsnyje pateikiami faktai papildo šių laikų etnomuzikologų ir etnoinstrumentologų Romualdo Apanavičiaus, Marijos Baltrènienès, Gailos Kirdienės, Vidos Palubinskienès, Algirdo Vyžinto, Rūtos Žarskienès ir kitų autorių šios srities darbus.

PAGRINDINIAI ŽODŽIAI: tradiciniai muzikos instrumentai, tradicinè instrumentinè muzika, etnoinstrumentologija, etnomuzikologija, terminija, muzikos teorija, muzikos istorija.
\end{abstract}

\footnotetext{
Abstract

The article is intended as a presentation and investigation of the historical terminology of traditional Lithuanian musical instruments, details of their construction, and their music-making features. The research material was collected after reviewing Lithuanian ethnomusicological literature from the end of the 19th century to the first decades of the 20th century, in order to find the earliest descriptions in the field of actual terminology. Most attention is paid to the historical works of Mikas Petrauskas (1873-1937), Pranas Puskunigis (1860-1946), Justinas Strimaitis (1895-1960), Mykolas Biržiška (1882-1922), Adolfas Sabaliauskas (1873-1950), and Teodoras Brazys (18701930). In this respect, traditional Lithuanian musical instruments are not studied in a systematic
} 
way, so the facts presented in this article supplement the work by the contemporary ethnomusicologists and ethno-instrumentologists Romualdas Apanavičius, Marija Baltrėnienė, Gaila Kirdiené, Vida Palubinskienè, Algirdas Vyžintas, Rūta Žarskienė, and others.

KEY WORDS: traditional musical instruments, traditional instrumental music, ethno-instrumentology, ethnomusicology, terminology, music theory, music history.

DOI: http://dx.doi.org/10.15181/rh.v28i0.2224

I va d a s

Straipsnis skirtas tradicinių muzikos instrumentų ir jų muzikos istorinei terminijai įvertinti. Medžiaga tyrimams surinkta peržvelgus XIX a. pabaigos XX a. pirmųjų dešimtmečių lietuviškus etnomuzikologinès literatūros šaltinius, siekiant aptikti ankstyviausius aptariamų muzikos instrumentų pavadinimų, ju konstrukcijos ir repertuaro aprašus. Daugiausia dèmesio skirta istoriniams Miko Petrausko (1873-1937), Prano Puskunigio (1860-1946), Justino Strimaičio (1895-1960), Mykolo Biržiškos (1882-1922), Adolfo Sabaliausko (1873-1950), Teodoro Brazio (1870-1930), kitų autorių ívairioje ano meto spaudoje skelbtiems tekstams. Šiuo aspektu sisteminiu būdu tradiciniai lietuvių muzikos instrumentai dar nebuvo tyrinèti, tad šiame straipsnyje pateikiami faktai nuosekliai papildo šių laikų lietuvių etnomuzikologų ir etnoinstrumentologų darbus.

Muzikos instrumentų terminijos ištakas ịvairiais aspektais tyrinejjo ir šio straipsnio autorius. Jie skelbti straipsniuose apie stiliaus ir žanro sampratos terminiją (Sliužinskas 1998; 2001), improvizacijos, stabilumo ir mobilumo sąvokas (Sliužinskas 2002a), T. Brazio, A. Sabaliausko, A. Juškos, M. Petrausko, M. Biržiškos terminiją (Sliužinskas 1999; 2002; 2003; 2014; 2019), kitus šios terminijos formavimosi aspektus (Sliužinskas 1999a; 2003a; 2004). Tradicinių muzikos instrumentų pavadinimus publikacijose iš istorinių šaltinių yra pateikę Zenonas Slavinskas-Slaviūnas (Slavinskas 1937; 1937a; Slaviūnas 1939; 1939a; 1955; 1955a; 1955b; 1959), Stasys Paliulis (Paliulis 1959; 1984), Marija Baltrènienè (Baltrènienė 1980; 1980a; 1989; 1997; Baltrènienè, Apanavičius 1991), Romualdas Apanavičius (Apanavičius 1992; 1994; 2001; 2003; 2009), Algirdas Vyžintas (Vyžintas 1975), Rūta Šimonytė-Žarskienė (Šimonytė 2000; 2001; 2003; Žarskienè 2007), Gaila Kirdienè (Kirdienè 2000; 2007; 2009), Vida Palubinskienė (Palubinskienè 2001), Gvidas Vilys (Vilys 2005; 2008), Evaldas Vyčinas (Vyčinas 2001; 2011). Čia paminètose ir dešimtyse kitų šių autorių publikacijų pateikiamas gausus pluoštas instrumentų bei jų konstrukcinių dalių pavadinimų, vartojamų tiek mokslinejje literatūroje, tiek gyvojoje pačių muzikantų kalboje.

Cituojant istorinius šaltinius yra paliekamos tuo metu vartotos žodžių gramatinès formos. Aptariami terminai išskiriami kursyvu. Neišvengiamai čia pastebi- 
mos ir kalbos svetimybės, keistenybės. Nesiekiama vertinti pateikiamų terminų ar sąvokų vartosenos rekomendacijų, tai paliekant kalbininkų nuožiūrai. Straipsnio tikslas - sisteminiu būdu surinkti ir pateikti skaitytojui aptariamų muzikos instrumentų ankstyvosios terminijos įvairovę. Publikacijos uždaviniai - apibūdinti daugiau ar mažiau sẻkmingas tokių terminų atrankos ir kūrimo proceso ištakas. Darbo rezultatai atsispindi tyrimo tekstuose bei išvadose, kur pateikiamos ir tolesnių mokslinių studiju šia tema perspektyvos.

Kanklių ir jų dalių terminai

Pranas Puskunigis - tradicinių kanklių žinovas. Jis 1932 m. išvardija visas pagrindines šio instrumento konstrukcijos dalis. Tai „liemuo, galva, rankena, stygos, mediniai varžykliai (šriubai) ir volelis. [...] Prie ilgojo šono, kairiojo kankliu galo prijungiama kankliu rankena. [...] Volelis arba virbalas yra ịkišamas į skylutes dvieju pritvirtintų medžio gabalèlių, vadinamų sargų. [...] Viršutinès kankliu lentos viduryje išpjaunama apskrita skylute su joje paliekamais šešiais sparneliais žvaigždutès pavidalo - tai kanklių garsiatakis“ (Puskunigis 1932, 7).

Šiuose jo raštuose ir kitų senųjų šaltinių (visų pirma A. Sabaliausko) tekstuose randame paminèta ir daugiau kanklių konstrukcijos dalių. Visų pirma apatinė ir viršutinė kanklių korpuso detalès. Tai apatine lenta - „apatinė lenta nekemėžno darbo, aptašyta tiesiog kirviu [...]“" (Lietuviškos... 1897) arba tiesiog medine dèžè - ,kanklés ant pažiūros yra tai į vieną galą susma[i]lyta mediné dėžé“ (Lietuviškos... 1897), dar vadinama liemeniu - „,savo liemeniu [...] kanklès gali tik pritarti [...]“ (Puskunigis 1932, 10), loveliu arba skrynele - „kankliai [...] tai išskaptuotas pailgas lovelis, arba skrynelè iš uosio ar klevo medžio [...]“ (Sabaliauskas 1911, 11). Viršutinè lenta ruošiama kruopščiau: „Užtaigi viršutine [kankliu] lenta paprastinai esti padabyta kaip galint gražiau“ (Lietuviškos... 1897) arba tiesiog kanklių viršus - ,kankliai [...] yra iš uosio ar klevo medžio su egliniu viršum [...]“ (Sabaliauskas 1911, 11).

Kanklių viršutinių lentų išvaizdai, jų estetiniam grožiui šiuose aprašuose skiriamas ypatingas dėmesys: „Niekuom nedažytos jų [kanklių] lentos nuo dūmų aptrauktos juodu dažu ir nuo rankų apsislidinę, žvilga tarsi užteptos juodu lekierium“ (Lietuviškos... 1897). Viršutinèje lentoje esančios žvaigždès pavidalo akustinès išpjovos (P. Puskunigis jas vadina garsiatakiais) vadinamos ir tiesiog garsais: „Daugiausiai marginiu apie [kankliu] garsus [išpjovas], kurie paprastai turi žvaigždès paveikslą“ (Lietuviškos... 1897).

Minimi korpuso šonai, platesnysis ir siauresnysis galai, siauroji pusė: ,[kankliu] šonai taipgi nedaug stropiau apdirbti“ (Lietuviškos... 1897); „Platesnysis kankliu galas yra nupjautas įstrižai, taip, kad į vieną šonq stygos eina vis trumpyn, o ị 
kitą - ilgyn“ (Lietuviškos... 1897); „Netoli siauresniojo galo eina skersai [...]“ (Lietuviškos... 1897); ,[...] deda kanklius ant stalo, arba ir ant keliu, siauraja puse i save“ (Sabaliauskas 1911, 11). Platesniojoje pusejje dažnai paliekama svarbi šio instrumento konstrukcijos dalis - kankliu galva, vadinamasis riestainiškas kanklių užrietimas: „Šis kankliu tipas - kiek pailgesnès ir su riestainišku užrietimu - [...] yra laikomas tikruoju“ (Puskunigis 1932, 9); ,[...] paliai kankliu galvq dedama medinè lentele [...]“ (Puskunigis 1932, 7).

Ittemptas stygas iš plačiosios ir siaurosios pusiu prilaiko geležiniai arba mediniai virbalai, virbalèliai, geležinis volelis arba tiesiog lentelè: „[...] prie kuriu yra prikabytas kitas galas užnarytųiu ant geležinio virbalo striunų“ (Lietuviškos... 1897); ,[...] prie antrojo galo - mediniai virbalai, ant kuriu antras kiekvienos stygos galas užsukamas, ir tokiu būdu styga ịtempiama [...] “ (Petrauskas 1909[1976], 42); „,...] vieton geležinio volelio [...] dedama medinè arba plieninė kelių centimetruc pločio lentele [...]“ (Puskunigis 1932, 7), „Netoli siauresniojo galo eina skersai geležinis virbalèlis, ant kurio užnarytos stygos (striunos) [...]“ (Lietuviškos... 1897).

Stygų įtempimą reguliuoja platesniajame gale įsukti ir iš viršaus įskelti mediniai kankliu šriubai, kuoleliai su galvukèmis: „,[...] šriubai mediniai, iš viršaus įskelti - į tą j̧skèlima ịspraudžia galą stygos“ (Lietuviškos... 1897); „[...] prie kurios ant įsuktų šriubų užneriamos kankliu stygos“ (Puskunigis 1932, 7); ,,[...] ant kurio ištemptos stygos prisukamos medžio kuoleliais“" (Sabaliauskas 1911, 11); ,[...] pakraščiui ịstrižai nupjautojo galo eina eile šriubu, prie kurių yra prikabytas kitas galas [...] striunu““ (Lietuviškos... 1897); „Norint atleist ar užveržti stygą, pasuka už galvukès šriubq iš apačios“ (Lietuviškos... 1897). Tam yra skirtas kanklių raktas arba rankenèlé: „Viršuje [...] kaip ir rankenèle - yra kanklių [derinimo] raktas“ (Puskunigis 1932, 8). Šiuos instrumentus nesunku pasigaminti: „Kanklių šriubus ir raktus gali padaryti kalvis arba šaltkalvis“" (Puskunigis 1932, 2).

Patys kankliu derinimo (pasak P. Puskunigio, - suderinimo, o pasak J. Strimaičio, - nustatymo, nutaisymo) būdai - „kanklių žangos (gamos)“ (Puskunigis 1932, 3), pagal atitinkamą formule - ,[...] paduoda ir formulą, kaip stygos suderinama“ (Petrauskas 1912[1976], 45). Ši formule labai paprasta: ,,[...] nurodysiu kankliu žangas (gamas) ir jų savybes, pagal kurias [...]" (Puskunigis 1932, 3); „Taisant striunas taiko kas penkta striuna (i kvintas), o kada penktos striunos nepritenka, taiso kas trečia (ị tercijas) - tokiu būdu sutaiko visas striunas“" (Lietuviškos... 1897); ,[...] suderinus reikia pagal gamos (žangos) eigą derinti kitas [kanklių stygas]“ (Puskunigis 1932, 10); „Kankliu derinimas reikalauja, kad septintasis gamos tonas būtų pustoniu žemesnis“ (Puskunigis 1932, 11); „,...] kad [kankliu] suderinimą geriau laikytuc [...]“ (Puskunigis 1932, 7). 
Plati ir įvairi yra kanklių stygų (dažnai - striunų, strūnų) įvardijimo terminija. Pradedant nuo ilgiausiųiu ir žemiausius garsus išduodančiųjų jos vadinamos savitai. Visu pirma tai kankliu boselis (žemiausiai derinama kanklių styga) - „Mažesnèsès [kanklès] yra senovinio tipo ir su boseliu“ (Puskunigis 1932, 9). Toliau eina pirmoji, drūtoji, ilgoji, arba storoji, styga: „[...] rodėsi mažoji sekunda tarp 2 ir 3 stygos, skaitant nuo drūtosios (tonikos)“ (Sabaliauskas 1916, VI); „Kanklininkas pradeda derinti stygas nuo ilgosios (tonikos)“"(Sabaliauskas 1916, VI); „Pirmoji arba storoji styga (tik ne boselis) derinama tone $d$, antroji tone e, ir taip toliau“" (Puskunigis 1932, 10). Kitos stygos dažniausiai įvardijamos eilès tvarka antroji, trečioji, ketvirtoji, penktoji, šeštoji ir t. t. Liudijama, kad „Stygu paprastai esti 9, 11 arba 13“ (Lietuviškos... 1897). Originalią plataus diapazono kanklių stygų pavadinimų sistemą yra pasiūlęs J. Strimaitis: „,[...] stygos kankliavimo [...] duoti sutrumpinti vardai, pav.: žemojoj oktavoj: vienka, duka, trika, keturka, penkka, šeška, sepka [...]. Vidurinëj oktavoj panašiai: vienna, duna, trina, keturna, penkna, šešna, sepna. [...] Aukštojoj oktavoj [...]: vientè, dutè, trité, keturté, penktè, šešté, septé“ (Strimaitis 1936, 49). Senuosiuose šaltiniuose kanklių stygos apibūdinamos dar įvairiau. Tai plonosios arba storosios stygos: „Skambinimo būdas - dviem pirštais [...] braukiant nuo storųju link plonųju [kankliu stygų] - gali būti panaudotas kanklèms suderinti“ (Puskunigis 1932, 14). Minimos tarpinés stygos: „Kiekviename naujame triskambyje bus kitos tarpinès [kankliu] stygos, kurias reikia užslopinti“ (Puskunigis 1932, 16). Suderintos stygos - nutaisytos stygos: ,[...] reikia bent 12 vieno tipo stygomis gerai nutaisytu kankliu“ (Strimaitis 1923). Pagal stygų gaminimo žaliavas jos skirstomos į vyniotas arba plienines: „,...] dvejas storąsias vyniotomis stygomis ir paprastas dvejas plieninemis stygomis“ (Puskunigis 1920 [cit. iš: Alenskas 1991, 12]).

Muzikuoti kanklèmis - skambyti, skambinti (su pirštais arba su tam tikrais pagaliukais), ant kankliu skambsti, kanklinti, kankliuoti: „Jau ir šiandien sunku rasti žmogų, mokanti ant kankliu skambyti““ (Lietuviškos... 1897); „Ar verta skambyti negeriems jauniesiems, kurie užmiršta savo tèvų palaikus..." (Lietuviškos... 1897); ,[...] vienas skambintojas negalèdavęs skambinti ant kito kankliu““ (Petrauskas 1909[1976], 42); „Skudučiavo (grojo) skudučiais, ragais (trimitais) ir skambino kanklemis“ (Strimaitis 1923a); „Iš jaunųju jau veik niekas nemoka ant kankliu skambsti“ (Lietuviškos... 1897); „Kanklindavo keturines giesmes ir kitus dalykus tame pačiame stiliuje“ (A. S. 1926, 43); „Nors retai, ir tik vèlesniu laiku, bet ir dainos kankliu[o]jama buvę“ (Sabaliauskas 1911, 12); „[...] kad visuose Tẻvynės kampuose užsikurtų noras kankliuoti, rinkti dainas ir kitokią tautosakq“" (Strimaitis 1923a). Rečiau - grajyti: „Grajijant pasideda ant kelių ir skambina stygas su pirštais arba su tam tikrais pagaliukais“ (Lietuviškos... 1897). Stygas dar 
galima užgauti ir tildyti: „Dešine ranka užgauna [kanklių] stygas, o kaire tildžia, uždėdamas pirštus ant stygų“ (Sabaliauskas 1911, 11).

Konstrukcijos požiūriu kanklès dažniausiai buvo skiriamos pagal savo stygų skaičių. Nors šiuo metu folkloro sąjūdyje yra populiariausios penkiastygès, devynstygès ir vienuolikastygès arba dvylikastygès kanklès, istoriniuose šaltiniuose minimas gerokai įvairesnis jų būrys. Čia įvardijamos penkiastygès, šešiastygès, septynstygès, aštuonstygès, devynstygès, vienuolikastygès, dvylikastygès, trylikastygès, keturiolikastygès ir net dvidešimt dvieju stygų tradicinès kanklès: „Ant aštuonstygiu kankliu skambinant aš nesu matęs. [...] vis tai buvo ant penkiastygiu kankliu““ (Sabaliauskas 1911, 12); „Pirmąii dalykèli [...] galima paskambinti ir šešiu stygu kanklemis“ (Budriūnas 1944, 5); „Seniau ir kitur buvo žinomi septyn-, devyn-, vienuolika- ir dvylikastygiai kankliai, dabar muzèjuose tebeužeinami“ (Biržiška 1921, 22); „Kanklių natų priedas pritaikytas dabar plačiau vartojamoms 11-14 ir 22 stygu kanklems, derinamoms G-dur tonacijos tonais [...]“ (Budriūnas 1944, 5).

Siekiant jas sugrupuoti, buvo žinoma bandymų skirstyti jas į atskirus tipus. Savo laiku P. Puskunigis siūlè įvardyti senąsias kankles keturių tipų ribose: I-IV tradicinių kanklių tipus: „I-asis tipas - penkiastygès kanklès, II-asis tipas septynstygès kanklès, III-asis tipas - devyniastygès kanklès, IV-asis tipas - vienuolikastygès kanklès" (Puskunigis 1933, 10). Tikruoju (pagrindiniu) tipu jis laikè pastarąsias, vienuolikastyges, kankles, „kiek pailgesnes ir su riestainišku užrietimu“ (Puskunigis 1932, 9). Kanklių konstrukcijos tobulinimo kontekste jos buvo skirstomos i paprastas (pustonines) ir tonacines (chromatines) kankles: „Yra tonacines, chromatinès, arba pustoninès, ir paprastos kanklès“ (Strimaitis 1935, 356). İ pirmąsias, ,ištobulintas“, kankles dažnu atveju būdavo žvelgiama su nepasitikèjimu: „Visokios „,balabaikos“, pertaisytos rusiškos citros perkamos pas mus kaipo „ištobulintos“ kankles" (Vilkolakas 1912). Tuo tarpu senosios, netobulintos kanklès meiliai vadinamos kanklytemis, kankleliais, skaptuotomis ar piemenu kanklemmis: „Tik gryčiose ir aukštuose svirnuose dar ilgą laiką dainoms pritardavo kankleliais mūsų tėvai ir tėvų tėvai“ (Strimaitis 1924, 28); „Skaptuotas kankles paprastai vadindavę piemenu kanklemis“ (Petrauskas 1909[1976], 42). Tradicinis kankliavimas vadintas liaudišku, terciniu, pamatuojančiu akordq: „Liaudiškq kankliavimq vadiname dar terciniu, kadangi skambinant liaudies dainas sopraną lydi dažniausiai lygiagretès tercès atstume altas (turavoné)“" (Strimaitis 1935, 359); „[...] kanklès, daugiau pamatuojančios akordą negu kulinès „remabalsis“ [...]“ (Petrauskas 1912[1976], 44)“; „[...] mūsų instrumentu kanklemis, kuris pajejgia duot akordq [...]. Dainavime galèjo būt akordas vartojamas, prieš padirbsiant kankles, ir tik kankles padare tuomet, kuomet jau klausa turëjo pasigavusi iš pajauty satarmés gamtos harmonijq" (Petrauskas 1912[1976], 44). Liudijamas ir 
kankliavimas pritariant ne tik daugiabalsėms, bet ir vienbalsėms dainoms: „Lietuvių buvo pritariama, ypač kanklemis savo vienabalsèms dainu gaidoms“" (Brazys 1920, 18).

$\mathrm{XX}$ a. pirmojoje pusėje jau pradejjus burti įvairaus dydžio ir diapazono kankles $\mathfrak{i}$ koncertinius ansamblius ir orkestrus, jas pradèta skirstyti ị solinio (tradicinio) ir orkestrinio tipų instrumentus: „Kun. Sabaliauskas pabrèžè būtiną reikalą valdybai kreipti visą energiją į kankliu tipus: solo, orkestrines ir t. t.“ (Buvęs klausęs 1925). Kanklių orkestre atsirado tonacinès kanklès - pikolès, pyplès, primos, altai, tercès, bosai, kontrabosai: „Tos mokyklos turima viso 16 kanklių: 1 pikole arba pyplè, 3 tercès, kitos visos primos ir vienas didelis (sulig žmogum aukštumo) kontrabosas“ (Strimaitis 1923); „Norint sudaryti suderintų kanklių orkestrèli, pridera pasigaminti keturių rūšių kankles. Tai yra pyplę, sopranukę prima, altukę ir boseli (Puskunigis 1920; cit. iš: Alenskas 1991, 12). Kitoje vietoje jau keliami didesni reikalavimai: „Gražiam orkestrèliui sudaryti koncertams rengti reikia bent 12 vieno tipo stygomis gerai nutaisytu kankliu: 3 pikoliu (pypliu), 4 primu, 4 altu ir vieno kontraboso" (Strimaitis 1923); ,[...] draugija stengiasi kankles tik orkestriškai suderinti: pikoles, primas, altus ir bosus - ir tiek“ (Strimaitis 1931). Čia jau minimas ne tik tradicinis, bet ir naujasis, pirštinis kankliavimo būdas: „Yra du kankliavimo būdai: liaudiškas ir pirštinis (naujasis)“ (Strimaitis 1935, 357). Buvo sumanyti ir rengiami naujojo kankliu muzikos orkestrinio sutvarkymo bei mokymosi kankliuoti nebe vien tradiciniu būdu vadovèliai: „Tatai bus nurodyta platesniame [kankliu] daugiabalsio skambinimo bei orkestrinio sutvarkymo vadovèly [...]“ (Puskunigis 1932, ii). „Šis kankliu muzikos vadovèlis buvo sumanytas [...]“ (Puskunigis 1932, 3).

Pastebime nostalgiškų komentarų apie anuomet jau pradejjusį nykti tradicinị kanklių skambesį: „Jau ir šiandien sunku rasti žmogų, mokantị ant kankliu skambyti“ (Lietuviškos... 1897); „Iš jaunųju jau veik niekas nemoka ant kankliu skambsti“ (Lietuviškos... 1897); „Smuikas su armonika užkariavo kankliu vietą, kanklès neišlaikè „kovos už būvį“ [...]“ (Lietuviškos... 1897“; „Kas gi dabar dèl muzikiško pasigerèjimo bevartoja kanklius, skudučius, lamždį? Jų vietą užèmė armonika, griežinè (skripka) [...] ir kiti“ (Sabaliauskas 1904, 31); „Tik gaila, kad jau labai retai kur gali rasti kankl[i]nyka, senieji baigia mirti, jaunieji paniekino kankles“ (Lietuviškos... 1897); „Kad suprasti, kaip maloniai skamba lietuviškos kanklès, reikia išgirsti nors sykį skambinant senovès kanklinykq" (Lietuviškos... 1897); „Visokios „,balabaikos“, pertaisytos rusiškos citros perkamos pas mus kaipo „ištobulintos" kanklès“ (Vilkolakas 1912). 
Skudučių terminija

Šioje srityje yra daug nuveikęs A. Sabaliauskas. Vartodamas pačiu skudučiuotojų terminologiją, jis $1911 \mathrm{~m}$. taip apibūdina šią kolektyvinio, ansamblinio pobūdžio muziką ir pačius instrumentus: „Yra tai dudelés nuo 12 lig 20 centimetrų ilgumo, iš jauno uosio grąžtu išgręžtos, bet nekiaurai; kiaurasai galas iš abiejų pusių paužulniai nupjautas, [...]“ (Sabaliauskas 1911, 12); „Vabalninkẻnuose vadina skudučiais (vienl. skudutis), Biržuose gi, Radviliškio pusèn, sako: skurdute, skurdutès“ (Sabaliauskas 1911, 12); „Skaitant nuo laibujų, vabalnykėnuose skudučiai vadinas taip: 1. tititiūtitiut, 2. tiūtititiūt, 3. kvepas, 4. untutis, 5. untyté, 6 ir 7. ūkai, arba kuldukai“ (Sabaliauskas 1916, VII); „Pirmasai skudutis vadinas tititiutitiut, 2-sai - tiutititiut, 3-sai - kvepas, 4-sai - untutis, 5-sai - untyté, 6-sai, laibesnis už pirmąij, - pridéčkas prie untytès, 7 ir 8-sai, tie drūtieji, vadinas ūkai arba kuldukai“ (Sabaliauskas 1911, 12); „Biržènuose skudučiai vadinas: 1. pirmoji (skurdutè), 2. antroji, 3. trečioji, 4. kvepas, 5. spjaudale ir 6. untytè. Ūku nèra“" (Sabaliauskas 1916, VII); „Prie kompleto priguli būtinai penki skudučiai, suderinti, kaip minètas penkiastygis. Skaitant nuo laibojo, jie teip vadinas: pirmasis, antrasis, kvepas, untutis, untyté; prie šios dar yra pridedama dar viena dudele, už pirmąii čielu vienu tonu laibesnè“ (Sabaliauskas 1904, 32); „Pravadorius, paduodamas vienam pirmaji skuduti, sako: „tu pūsk titi tiu titiut“, antram - antrąij ir sako: „tu pūsk tiu titi tiut“, trečiam duoda kvepa: „tu žinai, kaip pūst: ut ut üt“, ketvirtam - untutį: „o tu: ut, ut, un tititiut", pats gi pasituri untytę, t. y. vidudrūtajq̨ dūdelę ar aną vidulaibajq, vienas dvi pūsdamas; o aš, sako, pūsiu „,untyti ut, ut; untititi ut, ut“ ir t. t.“ (Sabaliauskas 1904, 32-33); „Kuldukai gi nuo untytès ir tarp savęs stovi čielų tonų intervale. Untytés pridèčkas laibesnis už pirmąị tititiutitiut - dideliu pustoniu“ (Sabaliauskas 1911, 12); „Skudučiu orkestro partijos turi šiuos senovinius pavadinimus: [...] ükas, [...], kvepas, [...] kuldukas [...], untytė [...], spiegas“ (Švedas 1936, 20); „Skudučiuojama taip pat giesmès [dainuojamosios sutartinès]. Tam imama arba pamatinis penkiastygis, arba - iš kitos tonacijos - nuo pirmojo ūko. Giesmes pučia dujenai: vienas ima pirma, trečiq, penktq, antras gi - antra ir ketvirta [skuduti]]“ (Sabaliauskas 1911, 13); „Prie pūtimo šitos meliodijos dar buk vartodavę du ūku, kurie buvę drūtesni už untytę" (Sabaliauskas 1904, 34).

Atskirai įvardijamos skudučiu konstrukcijos detalès: „Skudučio dalys: skudučio žiočiu viršūnè, landa, sienelès, dugnelis, didysis nusklembimas, mažasis nusklembimas [...]“( (Švedas 1936, 7).

Tradicinis skudučiu repertuaras - sutartinès. Yra žinoma didžioji skudučiu kompozicija - Septyniós: „Matyt, dažniausiai buvo pučiama vadinamoji Septyniós, ji todèl ir didžioji, nes nuo jos ir skudučiu vardai; joje vienas pučia tititiutitiu, 
antras - tiutititiut, trečias ju tarpe kvépuoja, iš to kvepas; ketvirtas sako: $\bar{u} t, \bar{u} t$, ūntititiut, delto - untutis; penktas - untyti, ūt, ùt, iš to untyté. Untytès priedas ir ūkai nebūtinai reikalingi“ (Sabaliauskas 1911, 12-13). „Kiekvienas skudutis turi savo varda, duotą jam [...] kompozicijoje, vadinamoje „Septyniõs“ (Sabaliauskas 1911, 12); „Kiekviena dūdelè turi savo vardą nuo to, kokią vietą užima toje didžiojoje skudučiu kompozicijoje, kuri Vabalninkėnuose vadinas Untytè ir Septyniós, o Biržėnuose Skurdute““ (Sabaliauskas 1916, VII). Kitas tradicinių skudučiu sutartinių repertuaras - eitiné, šešiõs, kvepas drūtesnis už untutĭ, škits katé, intakas: „Paduodu čia taip vadinamą „eitinę“, nes ją pūsdavo, esant baudžiavai, eidami dvaran arba grịždami“ (Sabaliauskas 1904, 34); „Ant skudučiú pučiama tam tikros kompozicijos, kurių aš turiu užrašęs šešias; jų vardai: a) septyniõs, b) šešiõs, c) kvepas drūtesnis už untutị, d) škits, katè, e) intakas ir f) eitiné" (Sabaliauskas 1911, 12).

Pagrindinių tradicinių skudučių komplektas - pamatinès skudučiu dūdelès: „Pamatinès skudučiu komplekto dūdelès - 5, bet didesnèms kompozicijoms vartojama da trys dūdelès“ (Sabaliauskas 1916, VII); „Pamatiniu skudučiu yra taip pat penki“ (Sabaliauskas 1911, 12). Pabrèžiamas tradicinis skudučiavimas lauke, atvirose vietose. Tai - oro muzika: „Skudučiai - oro muzika. Ju reikia klausyties iš toliaus“ (Sabaliauskas 1911, 13). Bandoma atsekti istorines skudučių kilmès ištakas: „Skudučiai tai bus Pano fleitos protèviai, kurią dabar vartoja italai, rumunai ir kiti“ (Petrauskas 1909[1976], 37). Minima ir svarbi skudučiavimo praktinè bei taikomoji vertè: „Skudučiu ir dūdeliu muzika galima pasinaudoti žygiuojant“ (Budriūnas 1944, 4).

\section{Trimituc pavadinimai}

Greta skudučių A. Sabaliauskas mini ir pagal muziką jiems giminingus medinius ragus: „Nežinau, dèl ko vadinas taip ilgos triūbos iš uosio medžio, tošia apvyniotos, bet žmonès vadina jas ragais; ar nebuvo jos seniaus iš didžių miško žvèrių ragų?“ (Žalia Rūta 1904, 34). „Ragai nèra tai instrumentai iš gyvulių ragų, bet iš uosio medžio. Vabalnykènai vadina juos triūbomis“ (Sabaliauskas 1916, VIII). Pabrèžiama gimininga skudučiams šių vėlgi išimtinai ansamblinio muzikavimo ragų sudètis: „Ragų komplektas taip pat - penki, suderinti, kaip skudučiai, ir tais pačiais vardais vadinami: kvepas, untutis, untyte [..."“ (Sabaliauskas 1911, 13). Ragų repertuaras taip pat giminingas tradiciniam skudučių repertuarui: „Ragais pučiant aš tegirdèjau ,Skurdutę“ ir „Ridika“ [...]“ (Sabaliauskas 1916, VIII); „Pučiant [ragais] „,septyniõs“, skudučių ūkų vietoje imama ilgesnis už untytę ragas, ant kurio galima išpūsti du kulduku tonu“ (Sabaliauskas 1911, 13). Esminis skudučiu 
ir ragų muzikos skirtumas - jų išgaunamų sutartinių garsų stiprumas: „Ragų balsas labai stiprus, už keleto varstų girdimas“ (Sabaliauskas 1911, 13).

Čia pat minimos ir daudytès, žinotos nuo senų laikų ir įvardijamos įvairiais kitais pavadinimais: „Gvanin’as aprašo ilgas medines dūdas, didinikais vadinamas...“ (Kraševskis, Biržiška 1921, 9); „,ie turi ypatingos rūšies trimitą, arba trombona, kuri vadina triūba [Truba]. Ši yra tuščiavidurè, iš eglès išskobta, apvalainai platejjančiu galu, kaip trombonas, iš viršaus tankiai apvyniota beržo tošimi, per sieksni ilgumo“ (Lepneris 1744 [2011], 194); „Ilgieji trimitai ir jais pritariamos sutartinès Žemaičiuose tebebuvę dar XVIII š.“ (Biržiška 1921, 22); „Trimytos - buvo tai kariškos labai didelès medinès triubos. Išnykus lietuvių karėms su jų priešais, išnyko ir trimytos“ (Lietuviškos... 1897). Jos dažnai vadinamos ir triūbomis, arba trimitais: „Pūsti ragais giesmes yra tam tyčia padarytos dvi ilgos triūbos, ilgumo lig 5 pèdų, tinkamai suderintos, kurios vadinas daudytès. Viena imama trys tonai, antra - $d u$ “ (Sabaliauskas 1911, 13); „Keturinėms giesmėms pūst taiso du ilgu ragu nevienodo ilgumo; jie išduoda po keletą balsų ir vadinas daudytès“ (Sabaliauskas 1916, VIII); „Trimitas būna nuo 2,5 iki 6 pẻdų ilgio. Ilgas trimitas duoda keliolika balsų, ir jeigu geras pūtejjas, tai ir melodiją išraliuoja su nuosekliais balsais [...]. Trimite jokių pypliu nèra“ (Petrauskas 1909[1976], 39); ,Yra kita ragų rūšis dèl pūtimo sutartinių [...]. Yra jie - dvi triubi ilgesni už anas paprastąsias ir vadinas: „,daudytès“ [...]“ (Sabaliauskas 1904, 34); ,,[...] Dabar tik prideda prieburnị, tankiausiai iš kaulo, prie kurio lūpas prispaudę, pučia trimitan [...]“ (Petrauskas 1909[1976], 39).

Deja, ano meto raštuose daudytès (triūbos, trimitai) labai dažnai painiojamos su mūsuc jau aptartais mediniais ragais: „Biržènai vadina ragais, o Vabalninkènai - triūbomis“ (Sabaliauskas 1911, 13); „Aukštaičiuose [...] senovès triūbosragai plačiau yra žinomi“ (Biržiška 1921, 22). Šioje citatoje M. Petrauskais ragais neabejotinai vadina daudytes: ,Jeigu paimtum raga ir pradètum jin pūst nuo pamatinés jo gaidos, tai gavę tolesniame pūtime eilę balsų iš didelès ir mažos tercijos [...]“ (Petrauskas 1912[1976], 45).

Pristatomas ir ambušiūrinis tradicinis piemenų aerofonas - ožragis, jo konstrukcija, instrumento būdas: „Ožio ragas dirbamas iš ožio rago“ (Sabaliauskas 1916, VIII)“; „Ožragis - iš ožio rago. [...] Jo balsas aržus, toli girdžiamas“ (Biržiška 1921, 23); „Patsai vardas [ožio ragas] išaiškina šio instrumento būdq“ (Sabaliauskas 1911, 14); ,[Ožio ragas] skyleliu turi tiek pat kaip lamždis, ir tirliuojama ant jo tas pat kaip ant lamzdžio" (Sabaliauskas 1911, 14). A. Sabaliauskas liudija ir jo garsų derinimo būdą: „Ožio ragas. Ar keturiomis skylelemis ir suderintas pagal ano penkiastygio; ypatingai ant jo „tirliuodavo“; tas užsièmimas prigulëjo piemenims ir pusberniams" (Sabaliauskas 1904, 36). 
Švilpynių ir birbynių vardai

Kitam tradiciniam piemenu pučiamajam instrumentui lumzdeliui skiriama daugiau dėmesio. Jis vadinamas dar ir dūdelèmis, vamzdžiais, vamzdeliais, lamzdžiais, lumždžiais: „Piemenys betgi vartoja savo darbo dūdas ir dūdeles, panašias i tas, kurias vartoja laukinès giminès [...]“ (Biržiška 1921, 21); „Dūdelè (vamzdelis) projektuojama vartoti visose pradinėse mokyklose [...]“" (Budriūnas 1944, 4); „Seniaus, mat, šokdavo ne pagal kokios nors muzikos - jei bent tikt pagal lamždi [...]“ (Sabaliauskas 1904, 27); „Lamždis. Pas mus sako: lumždis. Yra tai vargonų dūdos rūšis, ar iš uosio medžio, ilgumo kone pusantro sprindžio su keturiomis skylelemis. [...] Ant jo ịvairias meliodijas tirliuodavo [...]“" (Sabaliauskas 1904, 36); „Lamždis - vamzdis yra tai medinis instrumentas, išduodąs balsą pūtimu“ (Sabaliauskas 1911, 14). Aprašomas jo gaminimo būdas ir medžiagos: „Vamzdis, tarmiškai tariant, lumždis, išgręžiamas iš uosio medžio [...]. Yra tai daugiausiai piemenų instrumentas“ (Sabaliauskas 1916, VIII); „Pirmų pirmiausiai vamzdị dare iš žilvičio, gluosnio ar kitokio medžio žievès [...]. Vamzdị dirba šitaip: numauna nuo medžio žievę [...], viename gale išpjauna skylutę ir užkiša tą galą medeliu, tik ne visai, bet palieka plyšş oro praejjimui. [...] Tokiu pat būdu padaromas vamzdis, bet jau liemenyje su keliomis skylutemis, kurias uždarant ir atidarant pirštais [...] gaunama dar įvairesnè melodija“ (Petrauskas 1909[1976], 37). Skiriamas lumzdžiuoti ir mokyklu programose. İvairuoja jo korpuse išgręžtų skylučių skaičius: „Šio dainyno priede įdètos natos mokyklinei dūdelei yra pritaikytos paprastam vamzdeliui su šešiomis skylutėmis, [...]“" (Budriūnas 1944, 4). „,...] skyleliu turi tris, taip kad išduoda keturius balsus“ (Sabaliauskas 1911, 14).

Aprašomas ir dar vienas tradicinis piemenų pučiamasis instrumentas švilpa. Vẻlgi aprašoma jos konstrukcija, gamybos ir muzikavimo būdas: „Švilpa dirbama iš baltakarnio karklo lazdos, arba, tikriau sakant, iš jo žievès, kuri, pavasary atkutus, numaunama nuo medžio“ (Sabaliauskas 1916, VIII); „Švilpa. Būdas pataisymo kaip lamždžio, tikt trumpa ir be skylučių; piemenų darbas ir mažiems vaikams žaisti“ (Sabaliauskas 1904, 37). „Išdavimui [švilpos] balso storaji galq pataiso kaip lamždžiui, tik pučia švilpon ne iš galo, kaip lamzdyje, bet iš šalies, nelyginant kaip fleiton; laibgalis palieka kiauras“" (Sabaliauskas 1911, 14); „,...] žmogus švilpuodamas ranka gali pasiekti laibgali [...]“ (Sabaliauskas 1911, 14); „Iš léno pučiant [švilpa] išduoda drūtą balsq“ (Sabaliauskas 1911, 14); „[Švilpoje] skyleliu jokių, žinoma, be vienos drūtgalyj padarymui balso“" (Sabaliauskas 1911, 14); „Per savo ilgumą, kaip kiekviena ilga triūba, švilpa išduoda [...] daug balsų natūrališkujų“ (Sabaliauskas 1911, 14).

A. Sabaliausko raštuose aptinkama nemaža informacijos apie birbynę. Minimos jos konstrukcijos dalys, skirtumai nuo fleitinio aerofono lumzdžio. „O 
dirbo ją iš šiaudo, plunksnos arba medžio“ (Sabaliauskas 1904, 36-37). „Birbyné išsukama iš alksnio arba karklo. Ją galima padaryti iš žq̨sies plūksnos ir iš šiaudo" (Sabaliauskas 1916, VIII); „Kartais tokiai birbynei drūtgali apvynioja su tošia ir gerai toli pratęsia.“ Pabrěžiami šio aerofono garso išgavimo būdai. Tai „muzikos ịrankis, kuriame balsą daro liežuvélis“ (Sabaliauskas 1904, 36). „Birbyne skiriasi nuo lamždžio tik tuo, kad joje balsa išduoda liežuvèlis, kaip klernete“" (Sabaliauskas 1911, 14).

Bendratautinių instrumentų pavadinimai

M. Petrauskas taip apibūdina dūdmaišị: „Čia vèl nepasitenkinta vienu sopel$k a$ - rageliu, nors tas duodavo daugeli ịvairių balsų [...]. Pridèta dar antras ragas, didžioji sopelka, ir tas buvo žemesnis visa oktava [...]. Tas didysis ragas laikè vieną gaidą ištisai, ir ì „,dūdoriai“ vadina ūku. [...] Didysis ūkas neturèjo pirštams skylučių. [...] Didžiajame rage - sopelkoje įdèta ir pyplè iš nendrès, kaip ir mažajame, tik daug didesnè. [...] Dabar žmogus galèjo jau žaisti nuolatos, nes tą maišą dumtuvę nuolatos laiko po pažaste, ir kai ji pripučia pilną, tai bežaisdamas ilsis, o orą varo, spausdamas tą maišą žasčia (Petrauskas 1909 [1976], 41); „Taigi žmogaus sugalvota, kad tas oras reikia pasigauti ir tuomet jis nuolatos galès savo instrumentu birbti“ (Petrauskas 1909[1976], 40). M. Biržiška taip pat mini „,...] kulinę su ūku arba Labanoro dūdq vadinamą, [...] net Vilniaus dūdq vadinamą“" (Biržiška 1921, 24). Pateikiami šio instrumento dalių pavadinimai: „Dūdos dalys: 1) Kuline - avino maišas [...], 2) pūtiklis - anga orui pūsti, 3) žaleika - pusaršinis vamzdis, turịs 6 uždengiamas ir atveriamas skylutes, 4) ūkas - baso triūba [...]“ (Biržiška 1921, 24); „Kuline su ūku. [...] Buvusi iš avies kailio su medine dudele; pažastyje pakišta ir spaudžiama, drūtu balsu sakydavusi: u, u; vartodavę prie kitu muzikos innagiu““ (Sabaliauskas 1904, 37); „Putiklis, t. y. angelè (anga) orui pūsti; su tam tikru pritaisytu automatišku liežuveliu, kuris pats užsidaro nebepučiant, kad neišleistų oro, viduje esančio“ (Žiogas 1911, 109); „Žaleika arba sopelka. [...] Sopelkai - žaleikai pirštams skylutès taipgi išsvilinamos, [...] vidun jos įdedama iš nendrès ar žąsies sparno plunksnos pyplè. [...] Pyplę tankiausiai daro iš nendrès, plunksnos arba kitą kartą - ir iš kviečio šiaudo" (Petrauskas 1909[1976], 38); „Žaleika, t. y. pusaršinis ilgio vamzdis, su praplatintu galu del rezonanso, bent kiek rago formos“ (Žiogas 1911, 109); „Prie to galo pūtiklio, kuris yra maiše, pridejo ploną plèvelę ir, kulinëje orui esant tampresniam, labiau suspaustam, jis ir plèvelę spaudè prie pūtiklio sienelių, nustojus pūsti, ir oras bereikalingai neišèjo laukan“ (Petrauskas 1909[1976], 40-41); ,[...] įtaise ir pūtikli, volę pripūtimui oro, bet čia jam vèl nepasisekè, nes kai tik jis nustojo pūtęs, oras pradèjo savaimi eiti atgal iš maišo laukan“ (Petrauskas 1909[1976], 40); „Ragelis - ta pati sopelka, 
tik gale užmautas ragelis, dèl to skamba pilniau, skardžiau ir balsas gražesnis“ (Petrauskas 1909[1976], 39). M. Petrauskas dūdmaišio (kulinès) boseli (ūką) vadina „remabalsiu“: „,...] daugiau pamatuojančios akordq negu kulinès ,remabalsis“ [...]“ (Petrauskas 1912[1976], 44). Aprašomi ir muzikavimo šiuo instrumentu būdai: „Kulinè, t. y. iš odos maišas, kuri po pažastimi laikydami virtuozai sodiečiai, dar prieš dūduojant, pripūsdavo dvasios (oro), žaisdami gi vèl pūsdavo“ (Žiogas 1911, 109); „Ūkas, t. y. triuba-balsas, $71 \mathrm{~cm}$ ilgio. Jis paprastai, žaidžiant, nuleidžiamas žemyn“ (Žiogas 1911, 109); „Kulinè dūda: [...] maišas stovi, ūkas guli ant stalo, žaleika stati stovi“ (Žiogas 1911, 109); ,,[...] Kolaik [...] jis pučia savo vamzdi, tolaik tas leliuoja“ (Petrauskas 1909[1976], 40); Nusakomas ir nykstantis dūdmaišio paplitimo arealas: ,,[... , „Kuliné su ūku“, kitaip vadinamoji „, $d \bar{u} d a “$, arba „Labanoru $d \bar{u} d a “$, gan plačiai tebėra ikišiol vartojama tulose vietose Vilniaus gubernijoje irgi kiek dar Kauno gub.“ (Žiogas 1911, 108); „Tebemini dar žmonès kitur visai jau išnykusią [...] kulinę su üku arba Labanoro dūdq vadinamą, [...] net Vilniaus dūdq vadinamą“ (Biržiška 1921, 24); „,[...] tas jau visai išnykęs, tai kulinè su ūku“ (Sabaliauskas 1911, 14).

J. Žiogas greta išsamaus dūdmaišio konstrukcijos bei jo muzikos apibūdinimo 1911 m. mini ir dambreli, vadindamas ji bandurka, sudaryta iš dvieju sulenktų ir suartintų plieno štabelių bei liežuvèlio: „Dar man Gaideje būnant, vartojama buvo menkutis geležinis muzikos instrumentas, bandurka vadinamas. [...] Tas menkutis instrumentas susideda iš dvieju plieno sulenktų ir suartintų [...] štabeliu, kurių tarpe yra pirštais virpinamas plieno liežuvèlis“ (Žiogas 1911, 109-110). O gerokai anksčiau ji savo poemoje „Metai“ mini ir Kristijonas Donelaitis: „Lauras su pirštu dambreli skambino pūsdams [...]“" (Donelaitis 1818 III, 191-192).

Ivairių tautų tradiciniame muzikavime žinomi cimbolai, dar vadinami ir sunkliais: „Per vestuves ir per šokius buvo vartojami sunkliai (cimbolai)“ (Kraševskis, Biržiška 1921, 9).

Smuikas - bendratautis tradicinis instrumentas, aprašytas dar ir Kristijono Donelaičio „Metuose“: „Jokūbs, strūnas įtempdams, čirškino smuikq“" (Donelaitis 1818 III, 191-192). Ir jo terminijoje randame mums aktualių sąvokų. M. Petrauskas pateikia neteiktinus šiais laikais kalbiniu požiūriu jo konstrukcijos detaliu pavadinimus: „Prie ramstuko (,,podstavkos“), styginiuose instrumentuose [...]“ (Petrauskas 1916, 4); „Su griežtuvu (su smičium)“ (Petrauskas 1916, 7).

Būgnai ir kiti mušamieji instrumentai, idiofonai. M. Petrauskas čia savo laiku siūlè į muzikos instrumentų klasifikaciją įvesti trenksminiu muzikos pabūklu sąvoką: „Mušamieji instrumentai: būbnai, dideli ir maži, varpas ir varpeliai ir įvairiausi trenksminiai muzikos pabūklai mėgstami žmonių žemesnès kultūros“ (Petrauskas 1909 [1976], 42-43). Vèliau būgnus (ir pan.) jis vadina barškaliniais instrumentais: „Kiti bubinai [...], tai barškaliniai instrumentai, palaiko ri- 
tmo lygybę, bet be nustatydinto tono bildesis“ (Petrauskas 1916, 29). „Mušamųju instrumentu pas mus nedaug tèra, iš viso bus tik vienas būbnelis" (Petrauskas 1909[1976], 42).

Prabėgomis minimi molinukai (gaidžiukai, kumeliukai): „Dar vartojama Lietuvoje instrumentai, iš molio nužiesti ir išdegti, kaip tai: gaidžiukai, kumeliukai ir kiti su dviem, trim ir net keturiomis skylutėmis - pirštams uždengti. Jie švilpia taip, kaip ir vamzdžiai, bet priklauso vaikams“ (Petrauskas 1909[1976], 42). Nelieka nepastebèta ir manikarka: ,,...] buvo surinkta apie 300 liaudies muzikos instrumentų, kurių tarpe buvo [...] net „manikarka“ iš Biržų [...]“ (Žilevičius 1966, 11).

Dar XIX a. pabaigoje jau pradedama nerimauti, kad senuosius tradicinius muzikos instrumentus žmonių susibūrimuose vis dažniau pakeičia armonika (armoška): „Ju [skudučių, ragų, etc.] vietą užima armonika ir smuikas“ (Sabaliauskas 1911, 15); „,[...] už keliu dešimčių metų kankliu balsas visai paskęs armonikų, „katarinkų“, draskančių sielą balsų“ (Vilkolakas 1912). „[...] armoškos muzika nèra artima lietuvio dvasiai“ (Socius 1929, 8).

Muzikantai, muzikavimas, instrumentine muzika

Muzikantai apibendrinta prasme vadinami ir dūdoriais, smuikoriais: ,[...] duoda savo užkandas [...] taipojau dūdoriams ir smuikoriams" (Juška 1883[1955] II, 338). İdomi pastaba, kur dūdoriais įvardyti bažnyčių vargonininkai: „Žemaičiuose tūlose vietose vargonininką vadina „dūdorius“. Daugeliškènai nesako „,vargonais graija“, bet „dūduoja“ [...]“ (Žiogas 1911, 109). Muzikos instrumentų meistrai - ju dirbëjai: „Nemažai liaudies muzikantų nuotraukų, instrumentų dirbëju, dainininkų ir kt.“ (Žilevičius 1966, 11).

Visa tradicinè instrumentinè muzika - instrumentaliné, arba instrumentališka, muzika: „Šio dainyno prieduose duodama ir šiek tiek instrumentalines muzikos“ (Budriūnas 1944, 4); „Grynai instrumentališka muzika vèlai tik atsirado“ (Sabaliauskas 1911, 14). Patys instrumentai - muzikos ịrankiai, ịnagiai: „Lietuvis gan apsčiai ir ịvairių turèjo savo pramogai muzikos ịrankių“ (Sabaliauskas 1911, 15); „Mūsų visai kulturai lig prièmimui V. Kristaus mokslo esant žemame laipsnyje, ir muzikos ịrankiai buvo, matyt, primitiviški [...]" (Sabaliauskas 1904, 30); „Dainu garsu apstumas paaiškinamas dar muzikos - įvairių jos įnagiu (instrumentu) išduodamų garsų įtaka“ (Biržiška 1916, VIII). Ši muzika įvardijama turinti nacionališkus muzikos instrumentus: „Kiekviena tauta turi ne tik savo ypatingus [muzikavimo] būdus, bet ir savo nacionališkus muzikos instrumentus" (Lietuviškos... 1897). 
İvairiuose šaltiniuose apstu tiesiog išvardijamų atitinkamose vietovėse žinomų tradicinių instrumentų: ,Minėtame krašte užliko šitie mūsų muzikos ịrankiai: kankliai, skudučiai, ragai, lamždès, ožio ragas, birbyné ir švilpa; dar atsimena kulinę su ūku“ (Sabaliauskas 1904, 31); „,Svotba geria klètyje, šoka, dainuoja ir, su dūdomis, ožragiais, vamzdžiais, lamzdelèmis, smuikais, būgneliais ir trimitais grieždami, veda jaunąią iš klèties ị seklyčią“ (Juška 1883[1955] II, 338); „,[...] muzikos instrumentai: a) kankliai (kitur - kanklés); b) skudučiai (kitur - skurdutés); c) ragai [...] iš uosio medžio; d) vamzdis, tarmiškai tariant lumždis; e) birbyné; f) ožragis; g) švilpa“ (Niemi, Sabaliauskas 1911, VI-VII); „Senovès lietuvių muzikos įrankiai [...] buvo šie: ilgi mediniai trimitai [...], gyvuliniai, paskui mediniai ragai, paprastos birbynès, švilpinès, vamzdžiai, garsūs styginiai kankliai ir kiti [...]“ (Biržiška 1925, 42); „Lietuviai, be to, vartojo visokių rūšių švilpines: švilpas, vamzdžius, turtukles, tuturges“ (Biržiška 1925, 42); J. Čiurlionytès 1938 m. minimi liaudies muzikos instrumentai: „lamzdeliai, ožragis, ragas, smuikai, skudučiai, triūbos, vamzdelis" (Čiurlionytė 1938, 249-256), ir t. t.

XX a. pradžios ir pirmosios pusès raštuose bene labiausiai atskleidžianti pačių muzikantų kalbos bruožus yra senųjų muzikos instrumentų konstrukcijos dalių terminija. Tokią muziką ir jos instrumentus tyrę bei aprašę mokslininkai dažniausiai perimdavo kanklininkų, skudučiuotojų, dūdmaišio pūtejjų ir kitų muzikantų vartotas sąvokas ir jas vartojo savo raštuose.

Išvados

1. XIX a. pabaigoje - XX a. pradžioje lietuviškos etnomuzikologinès terminijos žodynas dar nebuvo susiformavęs, tad teko ne tik fiksuoti jau girdètus, bet ir kurti naujus instrumentinès muzikos terminus bei tikslinti tokių terminu sampratas. Jų etnomuzikologinès terminijos studijos yra aktualios ir dabarties mokslininkams - etnomuzikologams, etnoinstrumentologams, visiems lietuvių tradicinès muzikinès kultūros tyrëjams bei puoselètojams.

2. Daugeliu atvejų ano meto mokslinèje literatūroje minima tradicinių muzikos instrumentu terminija atspindi įvairiuose Lietuvos etniniuose regionuose pačių muzikantų vartotas sąvokas. Tik retais atvejais buvo bandoma siūlyti vienokius ar kitokius tokių terminų naujadarus.

3. Visi šie to meto bandymai praturtinti lietuvių etnomuzikologinès ir etnoinstrumentologinès terminijos žodyną vertintini kaip vieni esmingiausių pirmųjų šio darbo rezultatų, vèlesniuose kitos kartos mokslininkų raštuose leidę toliau ṣ̨̌ žodyną tobulinti, šlifuoti ir gryninti. Ne visos jų siūlytos sąvokos ir terminai buvo visuotinai priimti, tačiau verta pripažinti, jog tai yra dèsningas istorinis na- 
tūralios mokslo terminų atrankos procesas, kurio ženklia dalimi buvo ir minètų autorių mokslinès bei praktinès veikos palikimas.

4. Šiuos etnoinstrumentologinès terminijos ištakų tyrimus verta ir toliau tęsti bei sieti juos su šių laikų muzikinès terminijos paieškomis ir naujadarais. Taip bus galima atsekti istorines minètų terminų raidos ir viso jų kūrybos proceso trajektorijas.

\section{Šaltiniai ir literatūra}

A. S. 1926 - A. S. Mūsų kanklininkai. [Martynas Lapienė, Pranas Puskunigis, Vincas Bartuška]. Muzikos aidai, 3-6, p. 43.

Alenskas 1991 - Vytautas Alenskas. Pranas Puskunigis ir Skriaudžių kanklininkai. Klaipèda, [1991] (išleista autoriaus lëšomis).

Apanavičius 1992 - Romualdas Apanavičius. Baltu etnoinstrumentologija. Kaunas: Kauno lietuvių tautinès kultūros centras.

Apanavičius 1994 - Romualdas Apanavičius. Baltai ir jų seniausieji kaimynai etnoinstrumentologijos duomenimis. Lietuvos mokslas / Science and Arts of Lithuania, 2, kn. 2-3, 115-129 [Vilnius: Lietuvos mokslų akademija].

Apanavičius 2001 - Romualdas Apanavičius. Lietuvių ir latvių kanklès - tautų bendros kilmès liekana. In Acta Baltica (p. 114-127). Kaunas: Vytauto Didžiojo universitetas; Latvijos universitetas.

Apanavičius 2003 - Romualdas Apanavičius. Etninių muzikos instrumentų pagrindinès idejjos. Tradicija ir dabartis, 3, 18-34 [Mokslo darbų rinkinys. Klaipeda: Klaipėdos universiteto Liaudies muzikos katedra].

Apanavičius 2009 - Romualdas Apanavičius. Etninių muzikos instrumentų vardai ir jų atkuriamosios reikšmès - seniausių ūkininkavimo būdų tyrimo šaltinis. Acta Humanitarica Universitatis Saulensis: mokslo darbai, 8, 35-43.

Baltrènienè 1980 - Marija Baltrènienè. Lietuvių liaudies muzikos instrumentai, I. Vilnius.

Baltrènienè 1980a - Marija Baltrėnienè. Lietuviu liaudies muzikos instrumentai, II. Vilnius.

Baltrènienè 1989 - Marija Baltrėnienè. Instrumentinių sutartinių genezė. In Liaudies kūrybos palikimas dabarties kultūroje (p. 46-50). Kaunas.

Baltrėnienė 1997 - Marija Baltrėnienè-Gaščiauskaitè. Devyniastygès kanklès: kankliavimo tradicijos ir dabartis. Vilnius.

Baltrėnienè, Apanavičius 1991 - Marija Baltrènienè ir Romualdas Apanavičius. Lietuvių liaudies muzikos instrumentai. Vilnius: Mintis.

Biržiška 1916 - Mykolas Biržiška. Lietuviu dainos. Vidurinèms mokykloms vadovèlis. Vilnius.

Biržiška 1921 - Biržiška, Mykolas. Dainos keliais (Vadoveliui bent kiek medžiagos). Vilnius: „Švyturio“ "b-vè.

Biržiška 1925 - Mykolas Biržiška. Dainu istorijos vadovèlis. III leidimas. Kaunas: „Vyties“ bendrovès leidinys.

Brazys 1920 - Teodoras Brazys. Apie tautines lietuvių dainu gaidas (melodijas). Tilžè: „Švyturio“ b-vè.

Budriūnas 1944 - Motiejus Budriūnas. Pradinis dainynas. Dainuojamieji žaidimai, dainos [...], giesmès, natos mokyklinei dūdelei, skudučiams ir kanklèms. Kaunas: J. Petronio leidykla, 1944.

Buvęs klausęs 1925 - Buvęs klausęs. Kanklininkų darbų aidai. Lietuva, 274.

Čiurlionytė 1938 - Lietuvių liaudies melodijos. Tautosakos darbai, 5. Spaudai paruošè J. Čiurlionytė. Kaunas: Lietuvių tautosakos archyvas.

Donelaitis 1818 III - Kristijonas Donelaitis. Metai. III dalis: Rudenio gérybès. Karaliaučiuje, Hartungu spaustuveje. 
Juška 1883[1955] II - Lietuviškos svotbines dainos. Užrašytos Antano Juškos ir išleistos Jono Juškos. II tomas. Vilnius: VGLL [I leidimas - Sankt Peterburg, 1883].

Kraševskis, Biržiška 1921 - J. I. Krašiauskio Lietuviu dainos. Versta iš lenkų kalbos (vertimą išlygino M. Biržiška). „Vilniaus“ leidinys. Vilnius.

Kirdienè 2000 - Gaila Kirdienè. Smuikas ir smuikavimas lietuviu etninëje kultūroje. Vilnius: Kronta.

Kirdienè 2007 - Gaila Kirdienè. Lietuviu liaudies smuiko muzika. 100 kūrinių. Vilnius: Lietuvos liaudies kultūros centras.

Kirdienè 2009 - Gaila Kirdienè. Tradiciné rytu aukštaičiu vestuviu muzika (su 2 kompaktinèmis plokštelèmis). Vilnius: Kronta.

Lepneris 1744 [2011] - Teodoras Lepneris. Prūsu lietuvis. Parengè V. Gerulaitienè. Vilnius: LII, 2011. I leid.: Der Preusche Littau [...] von Theodoro Lepner, [...] Danzig, 1744.

Lietuviškos... 1897 - Lietuviškos kanklès. Garsas Amerikos Lietuviu, 30.

Niemi, Sabaliauskas 1911 - Lietuviu dainos ir giesmès šiaur-rytineje Lietuvoje. D-ro A. R. Niemi ir kun. A. Sabaliausko surinktos. Annales Akademiae Scientiarum Fennicae, ser. 13, T. VI. Helsinki.

Paliulis 1959 - Stasys Paliulis. Lietuviu liaudies instrumentine muzika: Pučiamieji instrumentai. Sudare ir paruošė Stasys Paliulis. Vilnius.

Paliulis 1984 - Stasys Paliulis. Daudyčiu poveikis sutartinių muzikai. Muzika, 4, p. 87-95.

Palubinskienė 2001 - Vida Palubinskienè. Tradicinis kankliavimas. Vilnius.

Petrauskas 1909 [1976] - Mikas Petrauskas. Iš muzikos srities. Lietuva, 1909 gegužès 28 - birželio 4 d. d., Chicago, Illinois. II leid.: Mikas Petrauskas. Straipsniai, laiškai, amžininkų prisiminimai. Sudare J. Burkaitė (p. 29-43). Vilnius: Vaga, 1976.

Petrauskas 1912 [1976] - Mikas Petrauskas. Lietuvių muzika. Laisvoji mintis, 35, 36, 37, 39, Chicago, 1912. II leid.: Mikas Petrauskas. Straipsniai, laiškai, amžininku prisiminimai. Sudarè J. Burkaite (p. 44-62). Vilnius: Vaga, 1976.

Petrauskas 1916 - Mikas Petrauskas. Mažas muzikos žodynèlis. Lietuvių muzikos konservatorija. Boston.

Puskunigis 1920 - Pranas Puskunigis. Kanklių muzikos vadovèlis. II laida [rankraštis].

Puskunigis 1932 - Pranas Puskunigis. Kankliu muzikos vadovèlis. III laida. Lietuvos kanklininku draugija. Kaunas.

Puskunigis 1933 - Puskunigis, Pranas. Kankliu tipai. Skautu aidas, 11, 10.

Sabaliauskas 1911 - Adolfas Sabaliauskas. Apie žiemių-rytiečiu lietuvių tautinę muzika ir muzikos instrumentus. Vilnius: M. Kuktos spaustuvè.

Sabaliauskas 1916 - Adolfas Sabaliauskas. Lietuvių dainų ir giesmiu gaidos. Lietuvos šiaurès rytuose surinko kun. A. Sabaliauskas [...]. Helsinki.

Slavinskas 1937 - Zenonas Slavinskas. Lietuvių kanklès. Tautosakos darbai, III, 244-320.

Slavinskas 1937a - Zenonas Slavinskas. Lietuvių tautos muzika. Naujoji Romuva, 4-5(314-315), $112,113$.

Slaviūnas 1939 - Zenonas Slaviūnas-Slavinskas. Lietuvių liaudies muzikos instrumentų tautiškumo klausimu. Naujoji Romuva, 2(515), 34-38.

Slaviūnas 1939a - Zenonas Slaviūnas-Slavinskas. Lankas - pirmykštis lietuvių muzikos instrumentas. Gimtasai kraštas, 1(21), 525-531.

Slaviūnas 1955 - Zenonas Slaviūnas. A. Juškos „Svotbinės dainos“. In Lietuviškos svotbinès dainos. Užrašytos Antano Juškos ir išleistos Jono Juškos. I tomas (p. 5-20). Vilnius: VGLL.

Slaviūnas 1955a - Zenonas Slaviūnas. „Svotbinès rẻdos“ tautosaka ir papročiai. Lietuviškos svotbinès dainos. Užrašytos Antano Juškos ir išleistos Jono Juškos. II tomas (p. 5-24). Vilnius: VGLL.

Slaviūnas 1955b - Zenonas Slaviūnas. „Svotbinès rẻdos“ pastabos ir paaiškinimai. In Lietuviškos svotbinès dainos. Užrašytos Antano Juškos ir išleistos Jono Juškos. II tomas (p. 569-594). Vilnius: VGLL. 
Slaviūnas 1959 - Zenonas Slaviūnas. Sutartinès: daugiabalsès lietuvių liaudies dainos. Parengè Zenonas Slaviūnas, T. 1-3. Vilnius.

Sliužinskas 1998 - Rimantas Sliužinskas. Stiliaus ir žanro samprata užsienio etnomuzikologijos moksle. In Mokslas Vakaru krašte. Lietuvos mokslas. 18-oji knyga (p. 285-294). Vilnius.

Sliužinskas 1999 - Rimantas Sliužinskas. Lietuvių etnomuzikologinès terminijos ištakos kun. T. Brazio (1870-1930) moksliniuose darbuose. Soter, 1(29), 67-78 [Vytauto Didžiojo universitetas].

Sliužinskas 1999a - Rimantas Sliužinskas. Lietuviškosios etnomuzikologinės terminijos ištakos. In Muzikos meno idejos ir keliai (p. 4-9). Klaipėda: Klaipėdos universitetas.

Sliužinskas 2001 - Rimantas Sliužinskas. Vakaru šalių etnomuzikologijos terminija: stiliaus ir žanro sampratos. In Vakaru Lietuvos muzika, kn. 1. Žurnalo „Tiltai“ priedas Nr. 7 (p. 36-41). Klaipèda: Klaipèdos universitetas.

Sliužinskas 2002 - Rimantas Sliužinskas. Lietuvių etnomuzikologinės terminijos ypatybės kun. A. Sabaliausko (1873-1950) moksliniuose darbuose. Soter, 7(35), 105-116 [Vytauto Didžiojo universitetas].

Sliužinskas 2002a - Rimantas Sliužinskas. Lietuvių etnomuzikologijos mokslo terminai XX a. pirmosios pusès raštuose: improvizacijos, stabilumo ir mobilumo sqqvoku raida. Tiltai, 3, 89-93.

Sliužinskas 2003 - Rimantas Sliužinskas. Lietuvių etnomuzikologinė terminija kun. Antano Juškos (1819-1880) liaudies dainų rinkiniuose. Soter, 11(39), 193-200 [Vytauto Didžiojo universitetas].

Sliužinskas 2003a - Rimantas Sliužinskas. Lietuvių etnomuzikologijos terminija (XX a. pirmoji pusè). Liaudies kultūra, 2(89), 32-34.

Sliužinskas 2004 - Rimantas Sliužinskas. Ankstyvoji lietuviškosios etnomuzikologijos terminija bei sąvokos: atradimai ir paklydimai. Tautosakos darbai, XX(XXVII), 84-95 [Lietuvių literatūros ir tautosakos institutas].

Sliužinskas 2014 - Rimantas Sliužinskas. Lietuvių etnomuzikologinès terminijos ištakos Miko Petrausko (1873-1937) moksliniuose darbuose. Gimtasai kraštas, 7, 12-20.

Sliužinskas 2019 - Rimantas Sliužinskas. Lietuvių etnomuzikologinès terminijos ištakos M. Biržiškos moksliniuose darbuose. Res Humanitariae, 26, 143-158 [Klaipėdos universitetas].

Socius 1929 - K. Socius. Kankliu atgaivinimo reikalu. Lietuvos aidas, 217, 8.

Strimaitis 1923 - Justinas Strimaitis. Atgaivinkime kanklių muziką. Lietuva, 250.

Strimaitis 1923a - Justinas Strimaitis. Senovés lietuvių muzikos koncertas. Lietuva, 130.

Strimaitis 1924 - Justinas Strimaitis. Kanklès - dainų palydovès. In Pirmoji dainos diena (p. 2731). Kaunas.

Strimaitis 1931 - Justinas Strimaitis. Kanklininkų d-jos visuotinis susirinkimas. Lietuvos aidas, 74.

Strimaitis 1935 - Justinas Strimaitis. Kanklių mokymas pradžios mokykloje. Tautos mokykla, $15-16,356-361$.

Strimaitis 1936 - Justinas Strimaitis. 25 linksmos dainelès ir liaudiškas kankliavimas vienam, dviem ir trims lygiems balsams: skiriamas pradžios mokykloms. Kaunas.

Šimonytė 2000 - Rūta Šimonytė-Žarskienė. Šiaurès rytų Europos tautų skudučių tipo instrumentų repertuaras. Lietuvos muzikologija, I, 129-140.

Šimonytė 2001 - Rūta Šimonytė-Žarskienè. Skudučiavimo ištakos. Darbai ir dienos, 25, 39-70.

Šimonytė 2003 - Rūta Šimonytė-Žarskienè. Skudučiavimas Šiaurès rytu Europoje. Vilnius.

Švedas 1936 - Jonas Švedas. Skudučiuok! Pamokymai ir natos mažam (skautiškam) skudučiu komplektui. Kaunas.

Vilys 2005 - Gvidas Vilys. Lekètai - signalinis ganymo instrumentas. Kürybos erdvès, 3, 20-24 [Šiaulių universitetas].

Vilys 2008 - Gvidas Vilys. Kleketų tipologija. Kürybos erdvès, 8, 31-40 [Šiaulių universitetas].

Vilkolakas 1912 - Vilkolakas. Dar apie kankles. Lietuvos žinios, 63.

Vyčinas 2001 - Evaldas Vyčinas. Būgnas Lietuvoje. Lietuvos muzikologija, 2, 157-168. 
Vyčinas 2011 - Evaldas Vyčinas. Idiofonai Lietuvoje. Naujas žvilgsnis. Lietuvos muzikologija, 12, 180-193.

Vyžintas 1975 - Algirdas Vyžintas. Skudučiai. Vilnius, 1975.

Žalia Rūta 1904 - Žalia Ruta [A. Sabaliauskas]. Sutartines ir musu muzikos inrankiai. DirvaŽinynas, 4, 25-39 [Shenandoah].

Žarskienè 2007 - Rūta Žarskienè. Zenonas Slaviūnas ir lietuvių etninè instrumentinė muzika. Tautosakos darbai, XXXIII, 262-277 [Lietuvių literatūros ir tautosakos institutas].

Žilevičius 1966 - Juozas Žilevičius. Lietuvių muzikologijos archyvo apybraiža. In Akademija ir koncertas. Profesoriui, kompozitoriui ir Muzikologijos archyvo organizatoriui Juozui Žilevičiui pagerbti (p. 11-22). Maria High School Auditorium. Chicago, Ill.

Žiogas 1911 - J. Žiogas, Apie „kulinę su ūku“. Lietuvių tauta. Lietuvių mokslo draugijos raštai, kn. II, d. I, 108-110.

\section{Rimantas Sliužinskas}

\section{THE HISTORICAL TERMINOLOGY OF TRADITIONAL MUSICAL INSTRUMENTS AND THE MUSIC-MAKING PROCESS}

Summary

The article is intended to present and investigate the historical terminology of traditional Lithuanian musical instruments, their construction details and music-making features. The research material was collected after reviewing Lithuanian ethnomusicological literature from the end of the 19th century and the first decades of the 20th century, in order to find the earliest descriptions in the field of actual terminology. Most attention is paid to the historical works of $\mathrm{Mi}$ kas Petrauskas (1873-1937), Pranas Puskunigis (1860-1946), Justinas Strimaitis (1895-1960), Mykolas Biržiška (1882-1922), Adolfas Sabaliauskas (1873-1950), and Teodoras Brazys (1870-1930). In this respect, traditional Lithuanian musical instruments have not been studied in a systematic way, so the facts presented in this article supplement the work by the contemporary ethnomusicologists and ethno-instrumentologists Marija Baltrėnienè, Romualdas Apanavičius, Algirdas Vyžintas, Vida Palubinskienè, Rūta Žarskienè, Gaila Kirdienè, and others.

When quoting historical sources, the grammatical forms of words used the time are left. The terms in question are distinguished in italics. Inevitably, the foreignness and strangeness of the language are also noticeable here. The aim is not to make recommendations for the use of the terms and concepts provided, leaving that to the discretion of linguists. The aim of the article is to systematically collect and present to the reader a variety of early terminology of musical instruments, and the more or less successful origins of the process of the selection, creation and development of these terms. 
All the personalities mentioned above are prominent and multifaceted Lithuanian public figures from the beginning of the 20th century. They are outstanding cultural and scientific figures, especially interested in the history, development, theory and practice of Lithuania's traditional musical instruments and music-making. Not only did they try to gather literature on the instruments and give a general overview of it, but also to systematise all knowledge about the terminology of their names, the parts used in their construction, and the music that was collected and published at the time.

At the end of the 19th and the beginning of the 20th century, a dictionary of Lithuanian ethnomusicological terminology had not yet been formed, so they had to not only accept already-existing terms, but also create new terms for instrumental music and refine the concepts of these terms. Their studies of ethnomusicological terminology are also relevant to contemporary scientists, ethnomusicologists and ethno-instrumentologists, and all researchers and cultivators of Lithuania's traditional musical culture.

These attempts to enrich the dictionary of Lithuanian ethnomusicological and ethno-instrumentological terminology at that time can be assessed as one of the essential first results of this work. The next generation of researchers was able to improve, polish and further refine this dictionary in their later writings. Not all the concepts and terms they suggested were universally accepted, but it is worth acknowledging that this is a natural historical process in selecting natural scientific terms, a significant part of which was the legacy of the scientific and practical work by the authors mentioned. 